\title{
Exploring Institutional Policies towards Achieving Macro Policy of Equal University Admission: A Case of a Selected University in Northwest Nigeria
}

\author{
Muftahu Jibirin Salihu ${ }^{1}$, Hazri Jamil ${ }^{2} \&$ Aziah Ismail $^{1}$ \\ ${ }^{1}$ School of Educational Studies, Universiti Sains Malaysia, Malaysia \\ ${ }^{2}$ Institut Penyelidikan Pendidikan Tinggi Negara (IPPTN), Universiti Sains Malaysia, Malaysia \\ Correspondence: Muftahu Jibirin Salihu, School of Educational Studies, Universiti Sains Malaysia, Malaysia.
}

Received: October 1, 2015

Accepted: December 21, 2015

Online Published: February 24, 2016

doi:10.5430/irhe.v1n1p170

URL: http://dx.doi.org/10.5430/irhe.v1n1p170

\begin{abstract}
The purpose of this investigation is thus to explore the perspective of policy implementers and policymakers' on issue related to institutional micro policies towards achieving equality of educational opportunities on access to university education in Nigeria. The investigation used qualitative approach for in-depth understanding of the problem using interview protocol and document analysis as instruments to obtain data and other relevant information for the study, the participants were purposively chosen from the University of the case study. From the study, while the amount of quota allocation has been challenging to some states, Sokoto State is struggling hard to fill the vacancies allocated to it due to the lack of qualified secondary school graduates to enroll in to university, despite the university is allocated in Sokoto with its prime constitutional purpose to ensure equality in the State. In spite of been it the State government sole responsibility for the provision of qualitative basic and secondary education, the university initiated various micro policies towards addressing the problem, among which are; University Matriculation Program to retrain the unqualified secondary school graduates to enable them to enroll in the various degree programs of their choices. Furthermore, the university inaugurated improvement committees which are working independently in making assessment in the areas of needs and advise the government respectively. While the university is accused of reserving vacancies for the Sokoto indigenes through their Matriculation Program, according to the findings of this study the Sokoto State government did not before implemented a single recommendations suggested to it by the improvement committees towards achieving equality of educational opportunity on access to university education.
\end{abstract}

Keywords: institutional policies, macro policy, equality, university admission

\section{Introduction}

Higher education has been recognized as a fundamental instrument for the construction of a knowledge economy and the development of human capital all over the world (World Bank, 1999). According to Peretomode (2007), higher education is the facilitator, the bed rock, the power house and the driving force for the strong socio-economic, political, cultural, healthier and industrial development of a nation as higher education institutions are key mechanisms increasingly recognized as wealth and human capital producing industries which only human capital can sustain growth most especially in developing countries (Kors, 2008). Furthermore, World Bank (2004) argued that higher education is fundamental to all developing countries if they are to prosper in a world economy where knowledge has become a vital area of advantage. The quality of knowledge which is generated in institutions of higher learning is critical to national competitiveness. Basically, it is only higher education that can sharpen the minds of the individual and help transform the society economically, socially and politically (Slaughter \& Rhoades, 2004). Similarly, Amandi (2010) emphasize that countries can only achieve sustainable development by improving through training in higher level, the skills of their human capital. Fundamentally, higher level manpower training has been recognized as a primary tool for national development, such high level educational provision enables the citizens to acquire skills and techniques which are ploughed into human productivity, creativity, competence, initiative, innovation and inventiveness (Ehiametalor, 1988).

The 1981 Constitution of the Federal Republic of Nigeria guarantees equality and equity for all citizens. However, 
the educational gap between Northern and Southern Nigeria is the trace of educational inequality in Nigeria, which started since the inception of western education in the country (Okoli, 2007; Umukoro, 2014). To address this problem, the Nigerian policy of access to higher education is aimed at equalization of educational opportunities to all citizens of the country. The policy aims at giving equal educational opportunities at the higher education level (Chimombo, 2005). As concord by Phillips (2005), the process of educational policy development begins with its guiding philosophy or ideology, influencing the ambitions and goals of the education system. However, this access to higher education and the specific notion of widening participation is predicated on the awareness that particular groups are underrepresented in higher education. As the higher education system expands, the question of who benefits from the participation, and the consequent privileges it offers, becomes critical. As Watson suggests, 'the one absolutely iron law about widening participation is that if you want the system to be fairer it has to be allowed to expand' (Watson, 2005, p. 56).

\section{Background}

The need to investigate the implementation of equality of educational opportunities is now generally accepted as one of the tools of educational reforms (Biodun, 2000). Much of the development of education in the modern era has been brought about in the name of equality of educational opportunity. This slogan has been used to justify the expansion of accessibility, facilities and the expenditure in education in a very imaginable way, (Flaming, 1974 cited in Imam, 2012). Also in the early 1940s, W. Lloyd Warner and his associates suggested that unrestricted access to education constituted equality of educational opportunity. It could be said, they claimed, that equality of educational opportunity is achieved "if all children and young people went to schools of their choices, access the learning materials and the resources, and also got equal treatments in respective of their social background (Warner 1944, p. 51).

In the Nigerian context, it will be recalled that the equal educational objective contained in the Constitution as cited earlier in the first page of this chapter, is of the philosophy of providing educational opportunities at all levels to all citizens (FGN, 1981). Sequentially, as it was also indicated in the introduction that the higher educational gap between Northern and Southern Nigeria as earlier pointed out is a trace of educational inequality in Nigeria, and that was what gave rise to the idea of equality of educational opportunities in the country (Aderounmu, \& Ehiametalor, 1985; Adeyemi, 2001). According to Kosemani (1995), the education disparities between Northern and Southern zones of Nigeria which resulted in making the policy on equality of educational opportunities are evident in terms of universities, teaching and learning resources, and the participation of males and females in education. There are also disparities between urban and rural schools and between education institutions owned and controlled by the Federal Government and those owned and controlled by the States and private agencies (Okobia, 2002).

Challenges faced in achieving equality of opportunity in education have been described in reports submitted by nations including Nigeria regarding the implementation of the UNESCO's Convention against Discrimination in Education, even in countries where educational opportunities are in general widely available; inequalities remain in the ability of all social groups to fully avail themselves of such opportunities. Social and cultural barriers and unequal opportunities manifested in access to quality education remain one of the most serious difficulties of national educational policies (UNESCO, 2010; UNESCO, 2013).

However, despite the fact that some Nigerian researchers have explored various scholarly works on access to university education (Okebukola, 2006; Moti 2010; Agboola, \&Ofoegbu, 2010; Bakare, 2012; Esomonu, \&Adirika, 2012; Dada, 2004), they mainly focus on constitutional rights of having access to university education. The available literature indicates that there are apparently very scarce number of related studies on equality of educational opportunity and educational policy in Nigeria. This shows that the duo is highly neglected despite their significance in promoting the present world of education (Amos \&Abdulkarim, 2013; Onwuameze, 2013; Amaele, 2003). In fact, none of the studies above has so far explored the implementation of the federal character policy of access to university education. In this view, there appears to be a gap in literature on education policy implementation in Nigeria, and a huge knowledge gap in equality of educational opportunity which necessitated the need for further studies to be explored in this area of study. This is the gap that this study primarily seeks to fill.

\section{The Case}

The case which forms the central focus of this research project is fringed on the manner by which policy implementation affects equalization of equal opportunities of higher education in relation to the provision of equal education opportunities for all in Nigeria. The site selected as case study is referred as the university in North Western Nigeria. Although University is owned, funded and controlled by the Federal Government of Nigeria via the National Universities Commission (NUC). The university has been chosen because its located in a educationally 
backward State (Sokoto) (FCC, 1994), which the Federal Character Policy of equality of educational opportunity of access to university education was created to reduce the huge inequalities existed in the area (FCC, 1996). Furthermore Sokoto has the largest quote system and catchment area to handle with compare to other universities in Nigeria (JAMB, 2008) which will no doubt affect the equality of educational opportunity of the community where the university is located (Sokoto).

\subsection{Sokoto State as Context Background}

Nigeria has 36 States, among which is Sokoto State in northern part of the country. The largest ethnic group in the state is mostly Muslims Hausa people, (sometimes grouped with Fulani as Hausa-Fulani). Sokoto has 23 local government areas out of Nigeria's 774 local government areas (Nkromah, 2007). Sokoto is the capital city, named after the said state and is considered as the largest city with a long history and which occupies the seat of the Sokoto Caliphate. The state has a total land area of 25,973 square kilometers with a total population of more than 4 million people (NPC, 2006). With respect to higher education institutions, Usman Danfodio University Sokoto is located in Sokoto town, Sokoto State. Other institutions in the state include the Polytechnic of Sokoto State, Shehu Shagari College of Education sokoto, the Sokoto State School of Nursing and Midwifery, Sokoto State College of legal and Islamic Studies, and newly established Sokoto State College of Agricultural Science, Wurno.

\section{Research Questions}

1. What are the problems associated with the implementation of the policy on equality of educational opportunities on access to university education?

1.1 How do the university policy players address these problems?

\section{Research Methodology}

This study is aligned with the methodological paradigm which uses qualitative and in-depth investigation of the phenomenon being studied. The implementation of a national policy is a process in which different people from different contexts and persuasions are involved (Maharaj, 2005). This process entails, amongst other things, interpretation of policy text, expectations of different actors, debates, tensions and negotiations, at the end of the implementation process, different participants interpret the outcomes, and the reasons for such outcomes, according to their personal expectations of the policy.

In order to understand such perspectives, one needs to select a research orientation that allows for the investigation of such subjective construction of reality. In a search for an appropriate methodology, I sought an approach that would help to gain in-depth understanding of the participants' of this research i:e Policy implementation. Within the methodological paradigm of a critical and interpretivist perspective, qualitative research was viewed as an appropriate approach in facilitating such understanding (Ball, 1990; Bowe 1992; Gala, 2001; Tronyo, 1994a \& 1994b; Ozga, 1987). This perspective has been chosen for this study because it would allow the researcher to have a critical and holistic view of the phenomenon being studied.

\subsection{Research Instrument}

As Eugene (2009) noted, in policy research, almost all likely sources of information, data, and ideas fall into documents and people. In affirm with that belief, the researcher chooses- interview protocols instrument and document analysis as methods for this Study. Moreover, DvoraYanow's (2007) asserted that document reading can also be part of an observational study or an interview-based project. Documents can provide background information prior to conducting interviews. In this study, both policymakers' and the policy implementers' would be interviewed by the researcher, at the same time the researcher had collected document for analysis from the two categories of respondents of the three organization involved in the study.

\subsection{Subject Informant of the Study}

Khan and Best (2006) stated that participants (population) consist of "any group of individuals that have one or more characteristics in common that are of interest to the researcher; it may be all individuals of a particular type or more restricted to any part of the groups". Normally the members of the research population must share some common specified characteristics which would render them eligible for being included within the research population (Bichi 2004, p. 454). In affirm with, the characteristics of the chosen subject informant was laid on the working experience in the field of policy making, policy implementation and related matters in the organization of the data collection.

Considering the nature of this research, participants were selected through purposeful sampling. Patton (2002) was of the view that purposive sampling, being a most common method, tends to bring together research participants who share the same criteria which fulfill the requirements for a particular research situation vis-à-vis research questions. 
Cresswell (2003, p, 185) posited further that qualitative research enhances the ability of the researcher to make comprehensive selections of the appropriate participants who, by dint if their intellectual disposition and possible promity to the site of the research topic, are best suited to give analytical responses to the questions which they would be assumed. It does not mean, however, that the researcher may be caused to resort to random sampling among the research population as random sampling is mostly associated with quantitative method of research.

The participants were selected from the university, Universities Commission and the Admission Body. Lincoln and Guba (1985) posited that the sizes of research samples are often inadequate to provide comprehensive information for qualitative research even though there is not set sample size for it. However, it has been suggested that a set of eight - ten samples is size enough to support data collection in qualitative research (Corbin and Strauss, 1990) due to the copious amount of data and the complex technicalities which are involved in qualitative research.

\subsection{Ethical Consideration}

In the conduct of any manner of research, researchers should tune the private life of the human elements to be used (Silverman, 2000 p. 201). Cresswell (2003) suggests that the researcher has an obligation to respect the rights, needs, values and desires of respondents. Miles and Huberman (1994) are explicit on the issues which researcher should be cautious about while collecting and analyzing data during researches. Therefore, in preparing the grounds for this research, the researcher confirmed to Christians' (2000) admonition to, first of all, seek the consent of the interviewer who should not be deceived in any way in the course of the interview just as their identities shall be treated in confidence and also their responses to be so treated.

In ensuring authenticity and credibility of findings Guba (1981) posted that a good researcher should be concerned with four issues the first of which is how to render credibility for his/her findings (truth value concern); secondly, how does a researcher determine the applicability of findings to other settings or respondents (applicability concern); thirdly, how can a researcher determine consistency in a similar context (consistency concern) and fourthly, how can it be determined that findings are without bias or selfish interests (neutrality concern). Waldendorf and Belk (1989) added a fifth concern which is; how can it be determined that the participants did not give false information (integrity concern). It has been observed that each research approach develops its own criteria for addressing the stated concerns (Lincoln \&Guba, 1985; Schwandt et al, 2007; Wallendorf\& Belk, 1989). Therefore, this research was in full conformity with all the above protocols.

\section{Data Analysis Procedures}

The raison d'etre for carrying out any research project is the collation of data. However, this in itself does not suffice for the research to be successful or to be seen as successful. For the data which have been collated to be comprehensive, they have to be analyzed in the most appropriate way which would make it possible for them to be interpreted into information. Therefore, data collection in a research borders directly on analysis and interpretation (Coffey \& Atkinson, 1996; Marshal \& Rossman, 2006; Strauss \& Corbin, 1998). Analysis of data generally, needs comprehensive guidance which, in this instance, would be in the form of the references that would be made to in the literature text of the research report.

The analysis of data was in line with Wolcott's (1994, p. 33) position that it is essential for the analyst to look for "patterned regularities" in the different aspects of the data involved reading the collected data over and over again in order to identify similarities and/or differences that may occur between the data and the whole scope of the literature review. Coffey \& Atkinson (1996) corroborated this view when they stated that "it is useful therefore, to keep coming back to the same data with fresh analytic perspectives" (p.16). Data collection is a veritable exercise in the conduct of any research and so, by this very quality, data collection becomes indispensable. However, there can be no collection of comprehensive data, which would provide the means for finding and implementing feasible solutions without, in the words of Coffey and Atkinson (1996, p. 2) "never collect data without substantial analysis going on simultaneously".

\section{Data Analysis}

7.1 What Are the Problems Associated with the Implementation of the Policy on Equality of Educational Opportunities on Access to University Education?

\subsubsection{Factors Affecting the Implementation}

The intended ideology of policy on equality of educational opportunity is to bridge the educational gap between the two regions of the country. This fact has been clearly established through responses from the interviewees in The University, The University Commission and the Admission Body as well as data from the documents obtained. 
When the researcher asked the respondents their views on the existing policy, they clearly stated that it is a very good policy looking at it from the perspective of development. For example one of the interviewee stated that: In any society, you will expect that there will be equal development so that a particular sector is not lagging very far from the rest. If it does, it becomes a drag-force. So, any meaningful policy should take into account every sector developing on the same line of the policy. (P2- University-I) Similarly, another participant emphasized that; Yes this is good policy because it makes room for equal representation and not a situation where others would be denied opportunities' this is because of the gap in education that exist in the country (P4-University-I)

However, factors effecting policy implementation are conceptualized as one of the stages of the policy process, nor can other stages be divorced from implementation. This implies that implementation analysis requires understanding of all stages which interact and influence each other. It should be recognized, however, that not all implementation problems can be identified during the stages that precede it. Many of the problems can only be discovered during the implementation stage, which is the primary interface between policy and practice. It should be noted that this study confines its scope to the implementation stage. The choice of this focus does not dispute the fact that some of the complexities that manifest during the implementation stages are as a result of events that occurred in other stages.

\subsubsection{The Allocation of Quota}

Towards the understanding of the problems associated to the implementation of this policy, one of the participants from the university revealed that: One of the major issues and challenges has to do with the states being able to meet up with the quota allocated to them. (P3- university-I)

Specifically, from the findings this has been identified as the major challenges but there are no restrictions in terms of implementation. When asked to particularly describe the challenges one of the respondents further elaborated: The challenges are of different forms, in some cases, some states produced more than the quota allocated to them while in some fields, yet again though unfortunate some they tend not to be meeting up and there are a lot of reasons you can adduce to this. For example, the individual states most especially if not specifically those favoured by the policy find it difficult to meet their quota, simply because those states "tag" as educationally backward has numerous problems with their basic education system and secondary school in other words which the university depend upon to recruits its students. (P1- University-I)

From the data it has been understood that this is because on several occasions these favoured states cannot filled in their quota allocated to them because of lack of qualified candidates from secondary schools. This problem indicated that there having several opportunities been missed by those states concern due to the inability to produce the qualified and required number candidates in to the university.

\subsection{Ways of Addressing Some of the Problems}

This section will discuss some of the ways of addressing some of the problems discussed above, which include, University Matriculation Program, and Committees on improvement of education.

\subsubsection{University Matriculation Program}

On of the lack of qualified candidates from the state's considered to be educationally backward to fill in their quota, universities come up with strategy of Conducting 'University Matriculation Program'. Each and every year the university admitted 3,000 candidates in their matriculation programme, with hope that at least $50 \%$ of them will pass out examination, and when they pass the examination they will be provided spaces in the university by means of admission in different programmes. It has been observed from the data documents (Universities enrolment capacity) that the average percent of spaces given to the university by the university commission is five thousand annually that is for one academic session. Furthermore, from the available records, it was indicated that the quota or percentage allocated to states that are tag as educationally backward cannot be filled in because the states cannot produce the required number of candidates for the vacancies, that is why the university initiated the matriculation program to re-train the school graduates who did not meet up the university entrance examination to qualify them for university admission

This is because without this program the university cannot get these candidates within the areas that are set to be the catchment area state of this University. Interviewees from the university further explained on this matriculation program: We came up with this program to help these states, otherwise we have to admit outside to fill our university quota but technically now we have some way if we have 3,000 candidate in our matriculation program and we are lucky, 1,500 have certify our requirement, pass over exam then we are only looking for 3,500 from 5000 given to us, and this 1500 it is like we have nearly manipulate for our local environment and they will also participate in the general admission examination which takes place. (P2- university-I). 
Another participant states that: It's our own initiative to help these states. And this program is purely founded by the university we do not received any resources for it, impact we even accused of running a separate program for the interest of some states (P1- university-I). Moreover, another interviewee explained that: Here in this university we have our tactics of helping the disadvantage states towards achieving equality of educational opportunity, by admitting secondary school graduates in to our university matriculation program who do not possess the university entrance requirement, and sometimes we offer them admission, advised to differed and re-enrol for secondary school certification examination. (P3- university-I)

Each and every year the university has to do everything possible to defend this university matriculation program. According to the findings every year in the policy meeting the university is being accused of reserving positions for the educationally less privilege states, and this indicated that the university is struggling within national scheme of things to help to towards achieving equality of educational opportunities on access to university education.

\subsubsection{Improvement Committee}

In responses to the problem of educationally backward states for their inability to produce the required candidates in to university to fill in the vacancies given to them, the finding of this study discovered that there are other measures taken by the university apart from the running of University Matriculation Program, which is partnership with various states government concern in order to make proper recommendations to them on various ways towards bridging the gap between the two regions of the country. When the researcher asked some of the respondents on what effort the university itself is making towards eradicating this challenge with these states that are educationally backward, one of them specifically explained: Yes this university particularly set up committees, committee for Sokoto state, committee for Zamfara state, committee for Kebbi state. The name of that committee is committee for improvement of education in Sokoto state, and this committee worked in collaboration with this state government and a report was prepared on how to move education forward (P1-univeristy-I)

These committees purely consist of the university communities usually the Vice Chancellor, Deputy Vice Chancellors, Registrar, Deans of faculties and Heads of departments. One of the interviewees who happened to fall in the category stated above explained that: For instance was a member of the committee Sokoto State for the improvement of education in Sokoto state, and we presented a comprehensive report to Sokoto state government, and the irony is that many state in the country heard about that report, they came, adopted it from Sokoto state and they implemented it while Sokoto state did not implement it. (P2- university-I)

The university management discovered that it is their responsibility to bring out alternatives to help the immediate environment to improve their equality of educational opportunities, because if The University is situated here in Sokoto and the university drawn its students largely outside Sokoto then the impacts of this university here are not achieved. Therefore, the university community is seriously working with the various state governments. Similarly, the university initiate meetings between ministries and the university to draw their attentions on the problems and various alternative solutions from the perspective of the university. Therefore, one of the ways of achieving equality of educational opportunity on access to university education in these states (Sokoto, Kebbi, Zamfara) is when people are participating in university enrolment otherwise the university would only be their own by virtue of its present here but serving others.

\section{Discussion of the Findings}

From the above analysis, there are certain measures taken to address this problem, for the inability of the disadvantage states within the catchment area of this university of study. The university came up with University Matriculation program (UMP), usually every year the university enrol students who graduated from secondary schools and did not meet up the requirement to get admission in to university, this program is run for one year, it is intended to prepared students to meet up the requirement and get admitted in to the university. This initiative was strongly recommended from both university commission and the admission body as so one of the ways this equality of gap of educational opportunity can be taken care up.

However, it should be noted that had it been the implementation process of this policy is not bottom-up the university would not have opportunity to come up this micro policy towards achieving the main policy objectives. Furthermore, the university went to further to create committees for improvement of education, these committees were established and funded by the universities, the responsibility of these committees is to make yearly assessment of primary, secondary and the enrolment of university education of the states across the Sokoto region, write their report and suggested way forward to these states concern and forward the report to the respective for implementation. However, it's unfortunate that most of these states do not consider these reports for implementation. One of the research 
participants who happen to be member of one these committees states that "... the irony is that many of States in Nigeria heard about these reports, came here adopted from Sokoto state and they implement it while Sokoto state didn't implement it..." This unfortunate development clearly shows the level poor commitment of the states government toward the implementation of the policy of achieving equality of educational opportunities.

From the above findings, it can be seen that the universities had made several efforts to see that less educationally developed states located within the catchment area of the university had catch up with their other counterpart, and the commitment of the implementing agency is assumed to be the most important factor towards having successful policy implementation but the findings are not supported of the other collation client which are the states government in the case of this study, Elmore (1980) consider the cooperation of collation client, interest groups and leaders as one of the most crucial element for the success of policy implementation.

\section{Recommendations and Conclusion}

It would be difficult to discuss the issue of equality of educational opportunities on access to university education in Nigeria without having a critical look at basic education which fertile the universities to admits and graduate its students, not far room this, it is noted that seeking access to tertiary institution is not just from senior secondary school (SSS), rather these things starts from the primary. How many people enrolled into the primary schools through States Universal Basic Education Boards of respective States Universal Education Boards (SUBEB), pass through that process, then to Junior Secondary School (JSS). That number would translate into Senior Secondary School (SSS) and that is still the number that would write senior secondary school examination and when write, what is their performance? This is what this section of the research questions discovers in attempt to understand other policy practices towards achieving equal access to university education in Nigeria. When the researcher asked one of the interviewees in the university, he explained that: Remember that there is a minimum standard for you to enter into tertiary institution and that minimum standard counts, if you write your West African Examination Certificate (WAEC) or National Certificate Examination (NECO) and unable to make 5 Credits with English and Mathematics as compulsory subjects, then you can't enrol into tertiary institution (P2-univeristy-I)

However, checks and findings from this study indicated these basic requirements has been the problem for most of the candidates from Northern Nigeria, particularly Sokoto region, this revelation was in line with what the policy implementers' (The universities) decries for that many states despite the policy favoured to them but they are not able to fill their quota because of their basic educational system was of poor quality. Thus they cannot produce the quality secondary school graduates with required credentials to meet the quota allocated to them. Another respondent from the university commission related reiterated that: The problem of achieving equality in Nigeria is no more no less but the problem of primary and secondary education because that was the number that translate to the university intakeBut it's sad that many states decries of their candidates fails to get admitted because the quota allocated to them as per away from the number of their applicants in the while other cannot even meet their quote due to lack of poor secondary graduates. (P2-univeristy commission -I) Further lamenting the situation another participant clearly stated that: To be frank with you, if these states did not wake up and revolutionalized their basic education system, I cannot tell you when they will catch up with their southern counterpart in terms of educational development (P3-admission body-I)

Some participants from the university further explained that something has to be done, from primary school to address the issue of equality of educational opportunities on access to university education in Nigeria. Lamenting their experiences on comparing the basis education of their time and now in terms of quality and productivity, many of the respondents explain the in their own days, it does not matter which secondary school you attended whether in the village school or in the city, the quality and standard of education was the same. From the findings and the analysis, almost all the respondents agree that there is no other practice towards achieving equality of educational opportunity than the restructuring of the basic education. Therefore, secondary school level should be looked into as it is the threshing floor for higher education, ill prepared students at secondary level lead to poor results in the School Certificate, consequently, those students will not be able to transit to higher level of education.

Conclusively, this short case study had explored the perspective of policymakers and policy implementers' on the issue of achieving equality of educational opportunities on access to university education using qualitative research methodology. The study explore the problem of policy implementation in relation to university education, discuss some of the measures taken by the university in order to address the problem which include the university matriculation program and committees of improvement to advise by the state government by the university. Furthermore, the study suggested certain recommendations towards achieving equality of educational opportunity on access to university education in Sokoto state, Nigeria. 


\section{References}

Aderounmu, O. W., \& Ehiametalor, E. (1985). An Introduction to the Administration of Schools in Nigeria. Ibadan: Evans Brothers.

Adeyemi, K. (2001). Equality of access and catchment area factor in university admissions in Nigeria. Higher Education, 42(3).

Agboola, B. M., \& Ofoegbu, F. I. (2010). Access to university education in Nigeria: A review. Benin City, Nigeria: University of Benin. Department of Educational Studies and Management, Faculty of Education.

Amadi, M. N., Adeyemi, J. K., Ogundiran, S. O., \& Awe, B. (2010). Issues and problems in higher education in Nigeria. Paper presented at National Open University of Nigeria. Lagos.

Amaele, S. (2003). Equality of man and equality of educational opportunities in Nigeria. Ilorin Journal of Education, $22(2)$.

Amos, A. A., \& AbdulKareem, Y. (2013). Equal Education Opportunity and Egalitarianism. National commission for college of educations commission, NCCE publishing.

Bakare, T. V. (2012). Access to Higher Education for National Development in Nigeria: Distance Education to the Rescue. Journal of International Education Research (JIER), 8(3).

Ball, S, J. (1990). Politics and policy making in education. London, Routledge.

Best, J. W., \& Khan, J. V. (2008). Research in Education (Tenth ed.). New Delhi: Prentice.

Bichi, M. Y. (2004). Introduction to research methods and statistics. Kano: Debis-co press \& publishing company.

Biodun, O. (2000). Crises of Education in Nigeria. Ibadan: Books Farm Publishers. Christian publishers.

Bowen, G. A. (2009). Document analysis as a qualitative research method. Qualitative Research Journal, 9(2).

Chimombo, J. P. (2005). Issues in basic education in developing countries: An exploration of policy options for improved delivery. Journal of International Cooperation in Education, 8(1).

Christians, C. G. (2000). Ethics and politics in qualitative research. In N.K. Denzin \& Y. S. Lincoln (Eds.), Handbook of qualitative research (2nd ed.). Thousand Oaks, CA; Sage Publications, Inc.

Coffey, A., \& Atkinson, P. (1996). Making sense of qualitative data: Complementary research strategies. Sage Publications, Inc

Corbin, J., \& Strauss, A. (Eds.). (2008). Basics of qualitative research: Techniques and procedures for developing grounded theory. Thousand Oaks, CA: SAGE Publications.

Creswell, J. W. (2003). Research design: Qualitative and Quantitative approach. CA: Sage Publication, Inc.

Dada, J. A. (2004). Access to Education in Democratic Nigeria: Issues and Problems. In Uya, E.O., Denga, D., Umeh, J., and Okoro, J. (Eds.), Education for Sustainable Democracy: The Nigerian Experience. University of Calabar Press, Calabar.

Ehiametalor, E. T. (1988). Perspectives on National development: A book of readings. Benin: University of Benin Press.

Esomonu, N. P. M., \& Adirika, B. N. (2012). Assessment of Access to University Education in Nigeria. Research Journal in Organizational Psychology and Educational Studies (RJOPES), 1(5).

Federal Republic of Nigeria. (1981). National policy on education. Lagos: Federal Government Press. Government Press.

Federal Republic of Nigeria. (1996). The Federal Character Commission Official Gazette: Abuja. F.C.C. (P. A 379).

Gale Group. (2001). Gale Encyclopedia of Psychology (2nd ed.). Gale Group.

Guba, E. G. (1981).Criteria for assessing the trustworthiness of naturalistic inquiries. Educational Communication and Technology Journal, 29(2).

Imam, H. (2012). Educational policy in Nigeria from the colonial era to the post-independence period. Italian Journal of Sociology of Education, 1.

JAMB. (2008). Admission bronchus to Nigerian Universities. Publication of the Joint Admission and Matriculation Board. Nigeria. 
Kors, L. A. (2008). On the sadness of higher education. The Wall Street Journal, 7(27).

Kosemani, J. M. (1995). Democratic Values and University Admissions in Nigeria. Nigerian Journal of Professional Studies in Education, 3.

Lincoln, Y. S., \& Gruba, E. G. (1985). Naturalistic inquiry. Beverly Hills, CA: Sage.

Maharaj, A. (2005). The development and implementation of school governance policy in the South African Schools Act (SASA) and the Western Cape provincial school education Act (WCPSA). Doctoral Thesis, University of the Western Cape.

Marshall, C., \& Rossman, G. B. (2006). Designing Qualitative Research (4th ed., Vo. 1.). Thousand Oaks, CA: SAGE Publications.

Miles, M. B., \& Huberman, A. M. (1994). Qualitative data analysis: An expanded sourcebook. Sage.

Moti, U. G. (2010). The challenges of access to university education in Nigeria. DSM Business Review, 2(2).

National Population Commission. (2006). National population census report. Abuja, Nigeria: National Population Commission.

Okebukola, P. (2006). Principles and policies guiding current reforms in Nigerian universities. Journal of Higher Education in Africa, 4.

Okobia, S. O. (2002). The Educational Imbalance between the Northern and Southern States of Nigeria: A re-direction of Educational Policies, An Inaugural Lecture. Abraka: Institute of Education, Delta State University, 13th March.

Okoli, E. (2007). Gender Disparity in Nigerian Education: Women's Experience of Barriers to Equal Educational Opportunity. ProQuest.

Ozga, J. (1990). Policy research and policy theory: a comment on Fitz and Halpin. Journal of Education Policy, 5(4).

Patton, M. Q. (2002). Qualitative interviewing. Qualitative research and evaluation methods, 3.

Peretomode, V. F., \& Chukwuma, R. A. (2007). Manpower development and lecturers' productivity in tertiary institutions in Nigeria. Journal of Education Studies, (English Edition), Poland.

Silverman, D. (1993). Interpreting Qualitative Data: Method for Analyzing Talk, Text and Interaction. London: Sage Publication.

Slaughter, S., \& Rhoades, G. (2004). Academic capitalism and the new economy: Markets, state, and higher education. JHU Press.

Strauss, A., \& Corbin, J. M. (1998). Basics of Qualitative Research. Techniques and Procedures for Developing Grounded Theory. Thousand Oaks.

Tronya, B. (1994). Critical social research and education policy. British Journal of Educational studies, 42(1).

UNESCO. (2010). EFA Global Monitoring Report 2010 - Summary. UNESCO Publishing.

UNESCO. (2013). EFA Global Monitoring Report 2013-14: Teaching and Learning: Achieving Quality for All. UNESCO Publishing.

Wallendorf, M., \& Belk, R. W. (1989). Assessing trustworthiness in naturalistic consumer research. Association for $\begin{array}{llllll}\text { Consumer } & \text { Research. } & \text { Retrieved 28, 2015, } & \text { from }\end{array}$ http://www.acrwebsite.org/volumes/display.asp?id=12177

Watson, D. (2005). Overview: telling the truth about widening participation. In Layer, G. (Ed.), Closing the Equity Gap: the impact of widening participation strategies in the UK and the USA. Leicester: NIACE.

Wolcott, H. F. (1994). Transforming qualitative data: Description, analysis, and interpretation. Thousand Oaks, CA: SAGE Publications.

World Bank. (1999). World development report, knowledge for development. Washington D. C: World Bank.

World Bank. (2004). Improving Tertiary education in Sub-Sahara Africa: Things that work. Report of a regional training conference, Accra, Ghana.

Yanow, D. (2007). Interpretation in policy analysis: On methods and practice. Critical policy analysis, 1(1). 